\title{
Impact of Quality and Brand Image on Brand Loyalty of Bosnian Smartphone Users: Theoretical Model Development
}

\author{
Isaa Jukićn \& Ensar Mekić \\ International Burch University, Sarajevo, BOSNIA AND HERZEGOVINA \\ Faculty of Economics and Social Sciences
}

Received 19 June 2019 • Revised 15 July 2019 • Accepted 25 July 2019

\begin{abstract}
The main purpose of this study is to provide conceptual theoretical framework with purpose to investigate effects of quality and brand image on brand loyalty of smartphone consumers in Bosnia and Herzegovina. Hypothesized relationships are to be investigated as this represents scientifically unexplored aspect of our daily lives. The methodology suggested to be used for data analysis is descriptive statistics and regression analysis in a case of quantitative approach whereby structured survey may be used as main data collection instrument. It is expected that results of this study will confirm hypothesized relationships. It is recommended for researchers to provide validation of the proposed model and investigate hypothesized relationships not only in Bosnia and Herzegovina, but also in other Western Balkan countries. The findings of this study will have implications for both scientists regarding their future scientific work, but also for practitioners in smartphones business regarding their marketing strategies.
\end{abstract}

Keywords: quality, brand image, brand loyalty, smartphones, Bosnia and Herzegovina, Western Balkans.

\section{Introduction}

According to report of Statista (2019), from year 2014 to 2020 there is a rise of $45 \%$ in smartphone users worldwide, which indicates that this is one of the future most innovations in ascendancy. As we can see from the results, there is a need for this study because today's life is unimaginable without smartphones and technology (Statista.com, 2019).

It is interesting to notice that decade ago it was very hard to find study about smartphones. At that point of time this device was still in form of it's, nowadays primitive cell phones. Significance of correspondence and keeping up the connections inside organizations brought about extraordinary importance of cell phones. Besides, cell phone is a gadget numerous customers can't appear to manage without. They utilize cell phone as an individual gadget to remain associated with loved ones and as an augmentation of their identity and singularity (Grant \& O'Donohoe, 2007). As innovation keeps on advancing, cell phones are increasingly developed. According to Ting et al (2011), the cell phone has advanced from basically a relational specialized gadget to a sight and sound machine known as smartphone (Ting et al., 2011). According to

${ }^{1}$ MA student.

(C) Authors. Terms and conditions of Creative Commons Attribution 4.0 International (CC BY 4.0) apply. Correspondence: Ensar Mekić, International Burch University, Francuske Revolucije bb, 71210 Ilidža, Sarajevo, BOSNIA AND HERZEGOVINA. E-mail: ensar.mekic@ibu.edu.ba. 
Persaud and Azhar (2012), the present writing is increasingly about portable showcasing works on utilizing the great cell phone, with its extremely constrained ability, contrasted with the present smartphones, which have practically boundless potential. In this manner, there is a hole in the writing with regards to smartphones.

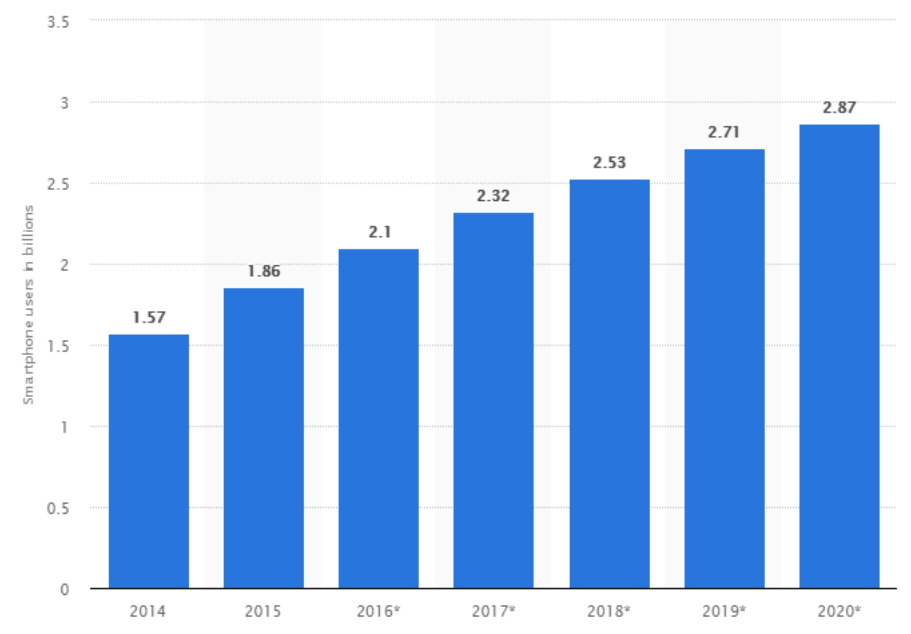

Figure 1: Number of smartphone users worldwide from 2014 to 2020 (in billions)

Having in mind insufficient attention of scientific researchers on smartphone related issues in Bosnia and Herzegovina Mekić and Özlen (2014), as well as complexity of Bosnian market the need and importance of this study is twofold, theoretical and practical.

Bosnia and Herzegovina was in a war from 1992 to 1995, and it is still in procedure of improvement. Despite the fact that joblessness rate is still high, numerous clients of Bosnia and Herzegovina are not late with regards to utilization of creative innovative gadgets such are smartphones, tablets and so on. Despite the fact that the versatile market is very re-imagined, and it turned out to be very hard to purchase basic cell phone rather than smartphone, there is still no experimental proof about components that invigorate clients to utilize smartphones in Bosnia and Herzegovina. Explanation behind leading this examination is the way that there is deficiency of writing about this issue in territory of Bosnia and Herzegovina (Mekić \& Özlen, 2014). Our study is response to theoretical gap that exists in Bosnia and Herzegovina when it comes to research about quality, loyalty and image perceptions towards different brands in smartphones industry.

Hence, this examination isn't imperative for organizations, retailers of cell phones, authorized wholesalers and servicers of different versatile brands situated in Bosnia and Herzegovina, yet additionally outside of its limits, this paper will give bits of knowledge to potential new organizations into Bosnian market of smartphones so as to fulfill clients. This work will experimentally distinguish factors that impact clients to utilize smartphones which is imperative data for potential new participants of Bosnian portable market (Mekić \& Özlen, 2014). Therefore, this study will help practitioners (smartphone retailers, wholesalers...) in Bosnia and Herzegovina to better understand factors affecting brand loyalty of smartphone users and improve their strategies accordingly.

The primary objective of this study is to understand factors affecting brand loyalty. The secondary objectives are as follows:

- To investigate effects of perceived quality on brand loyalty of smartphone users in Bosnia and Herzegovina; 
- To investigate effects of brand image on brand loyalty of smartphone users in Bosnia and Herzegovina;

- To understand differences in perceived quality, brand image and brand loyalty of smartphone users in B\&H having in mind respondents' differences in gender, age, income, and other relevant demographics

- To be roll model pioneer study and provide good grounds for future studies.

Structured survey compiled of previously validated scales will be used as a main data collection instrument. Methodology to be applied for purpose of data analysis in this study is descriptive statistics and multiple linear regression analysis. ANOVA methodology will be applied to investigate impact of demographical characteristics of respondents on variables (perceived quality, brand image, and brand loyalty). To provide all these analysis, Microsoft excel and software package for social sciences (SPSS 18) will be used.

Accordingly, the main research questions to be addressed by this study are:

- What are factors which are significant for brand loyalty of smartphone users in B\&H?

- How significant are effects of perceived quality on brand loyalty of smartphone users in Bosnia and Herzegovina?

- How significant are effects of brand image on brand loyalty of smartphone users in Bosnia and Herzegovina?

- Is there a difference in perceived quality, brand image and brand loyalty of smartphone users in B\&H having in mind respondents' differences in gender, age, income, and other relevant demographics?

The contribution of this study is threefold: theoretical, practical, and social. Theoretical contribution is assured by offering unique set of results never offered before by any researchers in the region of Bosnia and Herzegovina. Practical contribution is assured by giving valuable inputs to practitioners in smartphones sector of $\mathrm{B} \& \mathrm{H}$ and make them better understand ways to gain customers loyalty. Having in mind great impact of smartphones on society as a whole this study shall provide some contribution in that sense as well.

This study will be reported trough six sections. Literature review will help us identify variables, understand relationships and develop hypotheses. Section following literature review will graphically present key hypotheses through research model. Methodology section will explain in detail all procedures and statistical methods that will be applied to analyze collected data. After reporting findings under results sections adequate discussion and conclusion will be provided.

\section{Lecture review}

For purpose of this study, great number of relevant studies was addressed, and research model has been proposed.

\subsection{Definitions and concept evolution}

\subsubsection{Perceived quality}

Perceived quality of a product as turns into "the estimation made by the consumer relying on the whole set of basic as well as outer dimension of the product or the service" (Grunert, 
2005). Perceived quality is a basic component for customer decision making process; thusly, buyers will contrast the nature of choices and respect to cost inside a classification (Jin \& Yong, 2005). As indicated by Davis, Aquilano and Chase (2003), perceived quality is specifically identified with the notoriety of the firm that makes the item.

\subsubsection{Brand image}

According to Lee, Lee and $\mathrm{Wu}$ (2009), brand image as "perceptions about a brand as reflected by the brand association held in consumer memory". Brand image is the apparent capacities and representative relationship in the brain of clients and the quality and support of brand image relies upon the customer's esteem (Salciuviene et al. \& De Mattos, 2009).

\subsubsection{Brand loyalty}

According to Son (2010), brand loyalty is "a deeply held commitment to re-buy or repatronize a preferred product/service consistently in the future, causing a repetitive same brand or same brand-set purchasing, despite situational influences and marketing efforts having the potential to cause switching behavior".

\subsubsection{Smartphones}

The term Smartphone can be characterized as programmable cell phone that offers propelled abilities and highlights so as to improve the execution of people by giving the services, for example, texting, downloading applications, using information services, for example, WiFi, global positioning system (GPS) and stimulation (Ting et al., 2011). The Smartphone is acknowledged to be one of the major strides in the advancement of mobile marketing technology and practices due to its Bluetooth incorporation, area based advertising, and other coordinated advances with online and physical store promoting (Persaud \& Azhar, 2012). Smartphones give clients browsing messages, correspondence on person to person communication sites, and utilizing on the web visit paying little respect to time and place which make certain dimension of reliance on smartphone (Hudson, 2010).

\subsubsection{Smartphones in context of Bosnia and Herzegovina}

Despite the fact that Bosnia and Herzegovina is developing country, results of Mekic \& Özlen (2014) research showed that Smartphone users of B\&H are using these gadgets in numerous parts of their daily lives.

\subsection{Perceived quality and brand loyalty}

In 2015, Kim, Chang, Park, and Lee investigated the effects of quality on the satisfaction and the loyalty of smartphone users. They found that hypotheses was confirmed. Moreover, this study can be an important practical/academic reference to provide important hints to strengthen the relationship between the service providers and their customers (Kim et al., 2015).

According to study of Chen, Chen and Lin (2016) customers' perceived value, brand experience, trust, satisfaction, service quality and commitment are found to be the key influencing factors of brand loyalty. Related to the brand relationship quality for purchasing a smartphone, 
most respondents could hurriedly recall the symbolic logo of the brand and the after-sale service would affect their willingness of rebuying the same brand.

Brand loyalty expected to happen when perceived quality has been judged positively (Gürbüz, 2008). As per him when the client perceived the brand has extraordinary quality, they will create brand loyalty. He additionally expresses that perceived quality is the principle driver of brand loyalty and a positive quality assessment as a construct that keeps up social expectations. Boulding et al. (1993) states that there is a positive connection between perceived quality and brand loyalty and willing to recommend.

With respect to the connection between perceived quality and brand loyalty, a few investigations demonstrate a positive effect of perceived quality on purchase intention (Tsiotsou, 2006). Perceived quality is observed to be the primary forerunner of brand loyalty (Biedenbach \& Marell, 2009).

As indicated by the Alhaddad (2015) discovering demonstrate that perceived quality affects both brand image and brand loyalty, on other hand, whatever is left of connection between brand loyalty measurements and brand loyalty is affirmed.

In line with reviewed literature following hypothesis is proposed for this study.

H1: Perceived quality has positive effects on brand loyalty.

\subsection{Brand image and brand loyalty}

Brand image plays an important role when consumer evaluates service and product and it is a driving force for customer brand loyalty (Chen \& Myagmarsuren, 2011). According to them brand image influence attitudinal and behavioral response of customers toward brand, company and services. Kwon and Lennon (2009) also state that brand image crate strong company patronage intention among customers, and they are willing to pay premium prices and strong feeling and affiliation. As Pratama (2017) conducted in his study, result shows that brand image significantly has effect on brand loyalty when it comes to smartphone users.

Brand image is a standout amongst the most mind boggling elements and it influences loyalty in two different ways; first is customer prefer to show his own image and the second is individuals will in general arrange themselves into various social classifications that are assessment of targets and qualities in different gatherings in examination with customers' very own qualities and goal and they lean toward that who meet comparative objectives and values (Kuusik, 2007).

Brand image is one of the essential strides to achieve brand loyalty, in light of marking hypothesis it expressed that brand image must be compatible and parallel with the shoppers' image and it's a procedure and endeavor to meet mental and social needs. Moreover, brand image drives some critical component for the acknowledgment that is wealth, class, achievement, and style (Shehzad \& Zehra, 2013).

"Brand image" of cell phones has critical impact on "brand loyalty" to pre-adult purchasers, and "consumption behavior" of immature has noteworthy impact on "brand loyalty", while "brand image" and "consumption behavior" impact "brand loyalty" through altogether interceding impact of "perceived response" (Lin \& Chang, 2013).

In line with reviewed literature following hypothesis is proposed for this study.

H2: Brand image has positive effects on brand loyalty. 


\section{Hypotheses and research model}

The figure belov represents research model based on the literature review for this study. The model proposes two hypotheses. Besides all above mentioned studies, huge contribution for this study is research model proposed and investigated by Hwa-Kyung Kim and Timothy J. Lee (2018). It is important to say that even though the model proposed in our study is in line with their model, it is important to have in mind that their study tested the model in tourism context. As this study deals with smartphones, slight adjustment of the model has been conducted.

H1: Perveived quality has positive effects on brand loyalty.

H2: Brand Image has positive effects on brand loyalty.

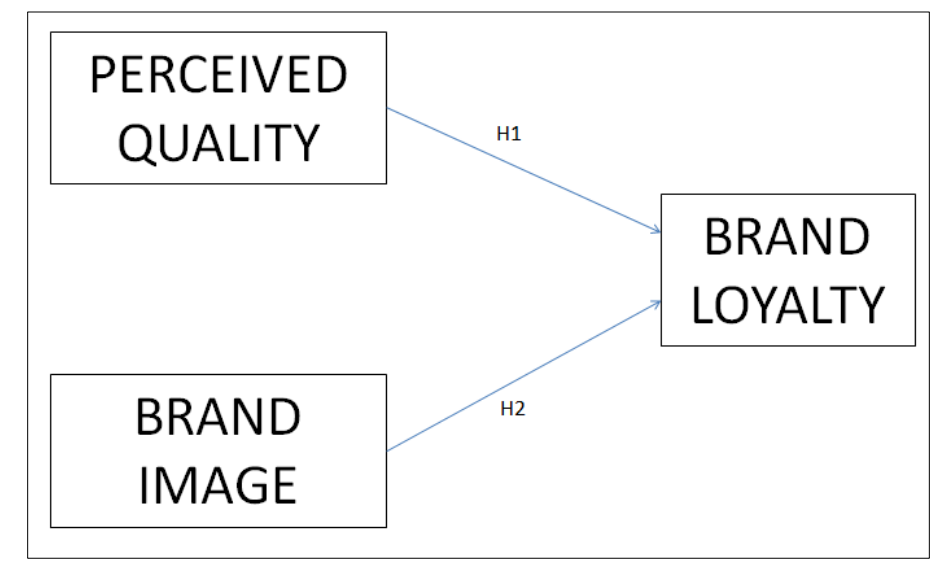

Figure 2. Research Model

Source: adjusted from Hwa-Kyung Kim and Timothy J. Lee (2018), and proposed for the study of smartphone users

Investigation of these hypotheses will help us answer following research questions:

- What are factors which are significant for brand loyalty of smartphone users in B\&H?

- How significant are effects of perceived quality on brand loyalty of smartphone users in Bosnia and Herzegovina?

- How significant are effects of brand image on brand loyalty of smartphone users in Bosnia and Herzegovina?

\section{Methodology}

Structured survey compiled of previously validated scales will be used as a main data collection instrument. Methodology to be applied for purpose of data analysis in this study is descriptive statistics and multiple linear regression analysis. ANOVA methodology will be applied to investigate impact of demographical characteristics of respondents on variables (perceived quality, brand image, and brand loyalty). To provide all these analysis, Microsoft excel and software package for social sciences (SPSS 18) will be used.

\section{Expected results}

In line with conclusions based on literature, it is expected that all hypothesized relationships among variables will be confirmed. However, it is suggested to conduct testing of the 
proposed model using adequate measurement scales. Replication of the study in different geographical contexts across different time periods is strongly recommended. Still, regardless of the positive and optimistic forecast on supporting the proposed research model, it is on future researchers to test the model and provide empirical evidence.

\section{Conclusion}

This literature review aimed to provide conceptual framework as a basis to investigate effects of quality and brand image on brand loyalty of smartphone consumers in Bosnia and Herzegovina. Hypothesized relationships are to be investigated for the first time among smartphone consumers in this region, and therefore, this paper may serve as a pilot study and good introduction for new studies addressing this important, yet scientifically unexplored aspect of our daily lives. The methodology suggested to be used for data analysis is descriptive statistics and regression analysis in a case of quantitative approach whereby structured survey may be used as main data collection instrument. It is expected that results of this study will confirm hypothesized relationships between quality and brand loyalty as well as brand image and loyalty. It is strongly recommended for researchers to provide validation of the proposed model and provide responses regarding hypothesized relationships in the region of Bosnia and Herzegovina. Furthermore, it is also recommended to test the model in other Western Balkan countries to have basis for comparative studies. The findings of this study will have implications for both scientists regarding their future scientific work, but also for practitioners in smartphones business regarding their marketing strategies.

\section{Acknowledgements}

This research did not receive any specific grant from funding agencies in the public commercial, or not-for-profit sectors.

The authors declare no competing interests.

\section{References}

Statista.com (2019, January). Retrieved from https://www.statista.com/statistics/330695/number-ofsmartphone-users-worldwide/.

Aberdeen, N., Syamsun, M., \& Najib, M. (2016). The effect of brand awareness and image on consumer perceived quality and purchase intension - A study case of carbonated drink brand at Bogor City. International Journal of Scientific and Research Publications, 6(8), 441-447.

Alhaddad, A. (2015). Perceived quality, brand image and brand trust as determinants of brand loyalty. Journal of Research in Business and Management, 1-8.

Biedenbach, G., \& Marell, A. (2009). The impact of customer experience on brand equity in a business-tobusiness services setting. Journal of Brand Management, 17, 446-458.

Boulding, W., Kalra, A., Staelin, R., \& Zeithaml, V. (1993). A dynamic process model of service quality: form expectations to behavioral intentions. Journal of Marketing Research, 30, 7-27.

Bruks, M., Zeithmal, V., \& Naylar. (2000). Price and brand name as indicators of quality dimensions for consumer durable. Journal of the Academy of Marketing Science, 28(3), 359-374. 
Chen, C., \& Myagmarsuren, O. (2011). Brand equity, relationship quality, relationship value, and customer loyalty: Evidence from the telecommunications services. Total Quality Management, 22(9), 957-974.

Chen, Y.-S., Chen, T.-J., \& Lin, C.-C. (2016). The analyses of purchasing decisions and brand loyalty for smartphone consumers. Open Journal of Social Sciences, 108-116.

Cole, R. E., \& Flynn, M. S. (2009). Automotive quality reputation: Hard to achieve, hard to lose, still harder to win back. California Management Review, 52(1), 67-93.

Davis, M. M., Aquilano, N.J., \& Chase, R. B. (2003). Fundamentals of operations management, 4th edition. Irwin: McGraw-Hill.

Egan, J. (2004). Relationship marketing: Exploring relational strategies in marketing. Harlow: Pearson Education.

Enck, W., Octeau, D., McDaniel, P., \& Chaudhuri, S. (2011). A study of android application security. Proceedings of the $20^{\text {th }}$ USENIX Security Symposium.

Genova, G. (2010). The anywhere office = anywhere liability. Business Communication Quarterly, 119-26.

Grant, I., \& O'Donohoe, S. (2007). Why young consumers are not open to mobile. International Journal of Advertising, 26(2), 223-46.

Grunert, K. (2005). Food quality and safety: consumer perception and demand. European Review of Agricultural Economics, 32(3), 369-391.

Gürbüz, E. (2008). Retail store branding in Turkey: Its effect on perceived quality, satisfaction and loyalty. Journal of Business, 3(3), 286-304.

Hudson, A. (2010). Measuring the impact of cultural diversity on desired mobile reference services. Reference Research Review, 38(2), 1-13.

Jin, B., \& Yong, G. (2005). Integrating effect of consumer perception factors in predicting private brand purchase in a Korean discount store context. J. Consumer Market, 22, 62-71.

Kim, H.-K., \& Lee, T. (2018). Brand equity of a tourist destination. Sustainability, 1-21.

Kim, M., Chang, L., Park, M., \& Lee, J. (2015). The effects of quality on the satisfaction and the loyalty of smartphone users. Telematics and Informatics, 32(4), 949-960.

Kuusik, A. (2007). Affecting customer loyalty: Do different factors have various influences in different loyalty levels? The University of Tartu Faculty of Economics and Business Administration Working Paper No. 58-2007, 29.

Kwon, W., \& Lennon, S. (2009). What induces online loyalty? Online versus offline brand images. Journal of Business Research, 62, 557-564.

Lee, M., Lee, C., \& Wu, C. (2009). Brand image strategy affects brand equity after M\&A. European Journal of Marketing, 45(7/8), 1093.

Lin, T., \& Chang, M. (2013). A study of the factors that influence the brand loyalty of Taiwanese adolescents with respect to purchasing mobile. Problems and Perspectives in Management, 11(2), 86-97.

Mekić, E., \& Özlen, M. (2014). Acceptance of smartphones by users in B\&H through extended. European Researcher, International Multidisciplinary Journal, 136-149.

Oliver, R. (1999). Whence consumer loyalty?. Journal of Marketing, 63(Special Issue), 33-44.

Pappu, R., Quester, P., \& Cooksey, R. (2006). Consumer-based brand equity and country-of-origin relationships. European Journal of Marketing, 4O(5/6).

Persaud, A., \& Azhar, I. (2012). Innovative mobile marketing via smartphones. Are consumers ready? Marketing Intelligence \& Planning, 418-443. 
Pratama, H. (2017). The effect of brand image, price, and brand awareness on brand loyalty: The rule of customer satisfaction as a mediating variable. Global Academy of Training and Research Journal, 469.

Salciuviene, L., Ghauri, P., Mockaitis, A., \& De Mattos, C. (2009). Brand image perceptions across cultures: a study of symbolic and functional associations. Advances in International Marketing, 20, 177191.

Shehzad, A., \& Zehra, M. (2013). Factors influencing the cell phone brand loyalty of Swedish generation. Västerås: Malarden University Sweden.

Shin, D. (2014). Effect of the customer experience on satisfaction with smartphones: Assessing smart satisfaction index with partial least squares. Telecommunications Policy, 627-641.

Son, K. (2010). Resistance to brand switching when a radically new brand is introduced: A social identity theory perspective. Journal of Marketing, 74, 128-146.

Ting, D., Lim, S., Patanmacia, T., Low, C., \& Ker, G. (2011). Dependency on smartphone and the impact on purchase behavior. Young consumers, 12(3), 193-203.

Tsiotsou, R. (2005). Perceived quality levels and their relation to involvement, satisfaction, and purchase intentions. Marketing Bulletin, 16.

Tsiotsou, R. (2006). The role of perceived product quality and overall satisfaction on purchase intentions. International Journal of Consumer Studies, 3o(2), 207-217.

Wei, R. (2008). Motivations for using the mobile phone for mass communications and entertainment. Telematics and Informatics, 25, 36-46. 
I. Jukić \& E. Mekić - Impact of Quality and Brand Image on Brand Loyalty of Bosnian Smartphone ...

C O A $\mathbf{s}$ 